\title{
SISTEM BANGUNAN RUMAH TRADISIONAL DI KAMPUNG ADAT BADUY LUAR KADU KETUG, KABUPATEN LEBAK, BANTEN
}

\author{
Andi Harapan ${ }^{12}$ \\ 1. Teknik Arsitektur, Fakultas Teknik dan Ilmu Komputer, Universitas Komputer Indonesia \\ 2. Arsitek,PT. BKM (Bamko Karsa Mandiri, A BITA Company) \\ Jl. Dipati Ukur No. 112-116, Lebakgede, Coblong, Kota Bandung \\ *Email: andiharapan@yahoo.com
}

\begin{abstract}
ABSTRAK
Traditional occupancy is something interesting to observe, especially when there are different types of dwellings in the residence, which illustrate the diversity of the culture and local knowledge of the people. Kadu Ketug Outer Baduy Traditional Village is a traditional village that has different residential patterns, where in this village, there are various types of traditional houses that show a wealth of traditions and carpentry technology, which are applied to the system of these houses. This mapping of traditional houses, as a form of intellectual property investment that is expressed in local knowledge, is very necessary to do with research and knowledge that can be applied to the development of technology in architectural technology. This paper will discuss the systems of traditional Baduy Kadu Ketug houses that were elaborated by descriptive analytical methods, from the results of field surveys and measurements in the field. The method of data collection was carried out by field surveys and interviews with traditional leaders and village communities, as well as recording through photographs and sketches of the buildings surveyed. The findings obtained indicate that the traditional house of the Outer Baduy Traditional Village of Kadu Ketug is an integral part of the Baduy Indigenous Village as a whole. This can be seen from the building layout, the building connection system, the use of materials, and the details of the building. The system of traditional houses in Kampung Luar Kadu Ketug implies a traditional Indonesian house hierarchy, which contains 3 parts, namely the lower part as the foot, the middle part as the body and the upper part as the head.
\end{abstract}

Keywords: Traditional House Building Systems, Traditional Village of Outer Kadu Ketug, Traditional Houses.

\section{PENDAHULUAN}

Suku Baduy merupakan salah satu suku adat yang berada di Indonesia, Suku ini pula merupakan Populasi masyarakat suku adat terbesar yang ada di Provinsi Banten. Dengan memegang teguh kepercayaan bahwa manusia dan alam mesti hidup secara berdampingan Suku ini juga merupakan suku yang keukeuh tetap menjalankan kepercayaan dan adatnya yang telah diwariskan turun temurun oleh nenek moyang mereka.

Lokasi pengamatan berada di Kampung tradisional Baduy Desa Kanekes, Kecamatan Leuwidamar, Kabupaten lebak, provinsi Banten, Indonesia. Kampung Baduy berada diketinggian 500 sampai 1.200 meter diatas permukaan laut yang lebih tepatnya kampung tersebut berada dilingkungan lembah pegunungan kendeng. Dengan suhu rata-rata kawasan sekitar 20 sampai 22 derajat celcius kawasan tersebut cukup sejuk dibandingkan daerah tropis lain yang ada di Indonesia.

Kawasan Baduy merupakan kawasan yang tidak bisa dilalui oleh kendaraan walaupun kendaraan roda dua sekalipun sehingga bilamana ingin mengakses kawasan ini mesti dilakukan dengan cara berjalan kaki, juga kawasan Baduy ini tidak dialiri listrik karena kawasan ini menjaga dogma bahwa tidak semuanya hal yang dari luar itu baik. Kampung ini juga dialiri oleh beberapa cabang sungai dan banyak ditumbuhi oleh pohon durian. Dan biasanya pemisah antara desa satu dengan desa yang lain dengan penanda pembatas sungai, ladang, maupun hutan. 
Terdapat sekitar 62 kampung adat baduy diantaranya 59 Suku baduy Luar dan 3 diantaranya suku baduy dalam. Baduy merupakan kampung adat yang terbesar di provinsi Banten Karena Baduy sendiri sudah terpecah dan menyebar sebanyak 62 suku Baduy dengan populasi masyarakat adat sebanyak 11.719 jiwa. (data desa kanekes) dengan demikian pula warga desa Baduy terus memperluas wilayah dari masa ke masa. Dengan banyaknya 62 kampung adat, daerah tersebut dibagi berdasarkan sistem RW dan RT. Suatu komplek dusun dengan banyaknya kampung diberi nama perwilayah dengan sebutan RW, dan RT dipisahkan dengan Batasan masingmasing kampung yang berada di suatu komplek dusun.

Lokasi Kampung Adat Baduy berada di Kampung tradisional Baduy Desa Kanekes, Kecamatan Leuwidamar, Kabupaten lebak, provinsi Banten, Indonesia (Gambar 1).

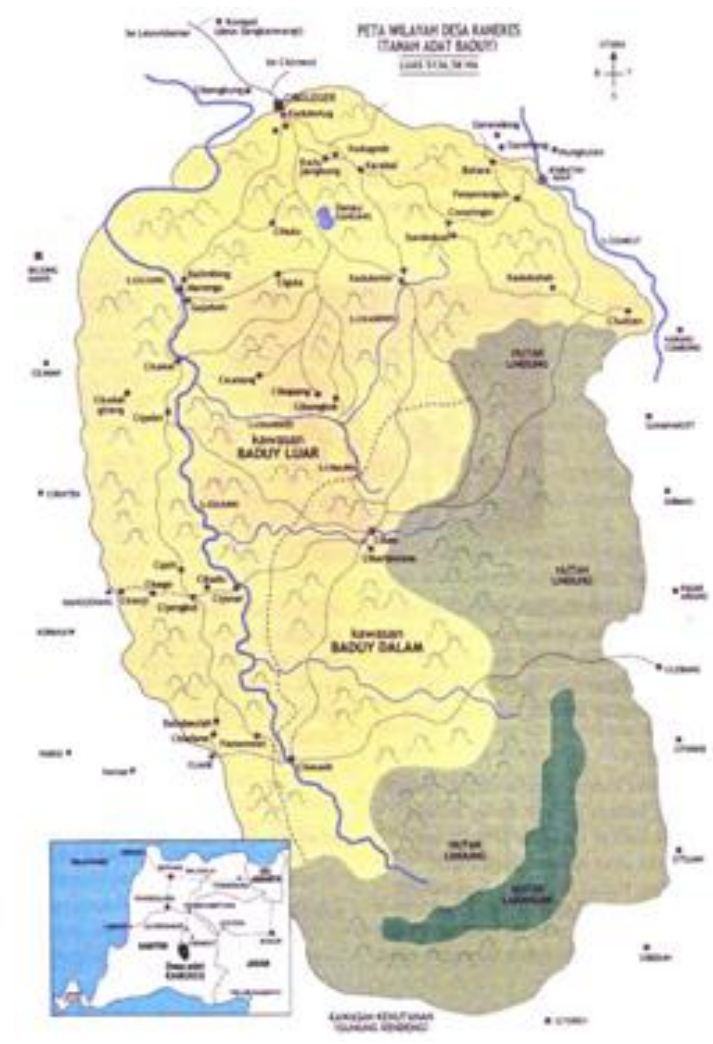

Gambar 1. Keyplan Kampung adat Baduy seluas 5136,58HA.
Metode yang dilakukan untuk penelitian ini adalah metode pengamatan dan pengukuran bangunan di lapangan. Pada tahap pertama, dilakukan pengamatan bangunan melalui foto visual baik bagian luar maupun bagian dalam bangunan. Adapun tujuan pengamatan ini adalah untuk memetakan jenis bangunan tradisional di Kampung Kadu Ketug. Pada tahap kedua, dilakukan pengukuran setiap tipe bangunan, termasuk pengukuran setiap detail bangunan. Pada tahap terakhir dilakukan mendokumentasian setiap bagian bangunan tardisional dalam bentuk gambar terukur, dengan tools CAD. Pada penelitian ini, bangunan diamati dalam 3 bagian, meliputi: 1) bagian bawah, 2) bagian tengah, dan 3) bagian atas. Setiap bagian mempunyai sub-sistem dan pada setiap sub sistem juga mempunyai sub sistem lagi (komponen), yaitu: bagian atas (sub-sistem atap dan langit-langit), bagian tengah (sub sistem dinding, kolom dan balok), dan bagian bawah (sub sistem lantai dan pondasi).

\section{HASIL DAN PEMBAHASAN}

\section{Tipe bangunan tradisional di Kampung Kadu Ketug \\ Bangunan di Kampung Kadu Ketug} terdiri atas 4 jenis tipe bangunan, yaitu: 1) bangunan rumah ketua adat, 2) bangunan rumah warga (tipikal sama), 3) bangunan leuit, dan 4) bangunan jamban (fasilitas bersama).

\section{Bangunan tipe 1: bangunan rumah ketua adat \\ Bangunan Ketua adat disini adalah} Bangunan Ketua adat yang sifatnya tingkatan pemerintahan, karena kepala yang sesungguhnya atau yang biasa yang disebut Puun berada di desa cikeusik kawasan Baduy Dalam dimana Orang diluar Baduy dilarang masuk ke Kawasan tersebut (Gambar 2, 3,4 dan $5)$.

\section{METODA PENELITIAN}




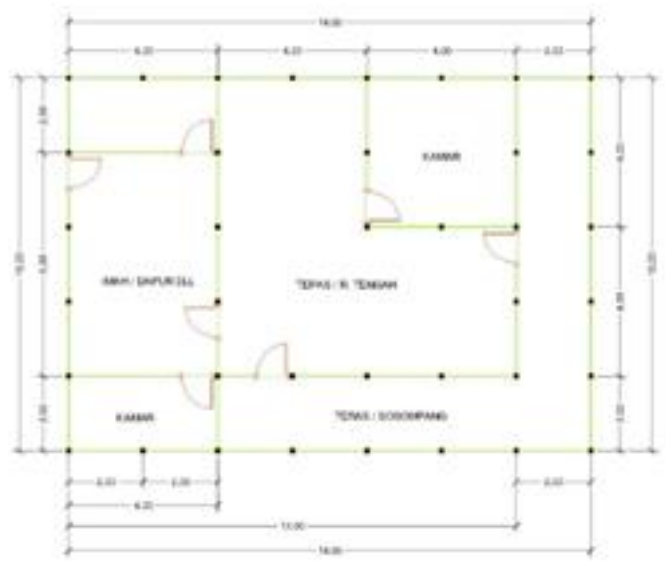

Gambar 2. Denah Rumah Ketua Adat

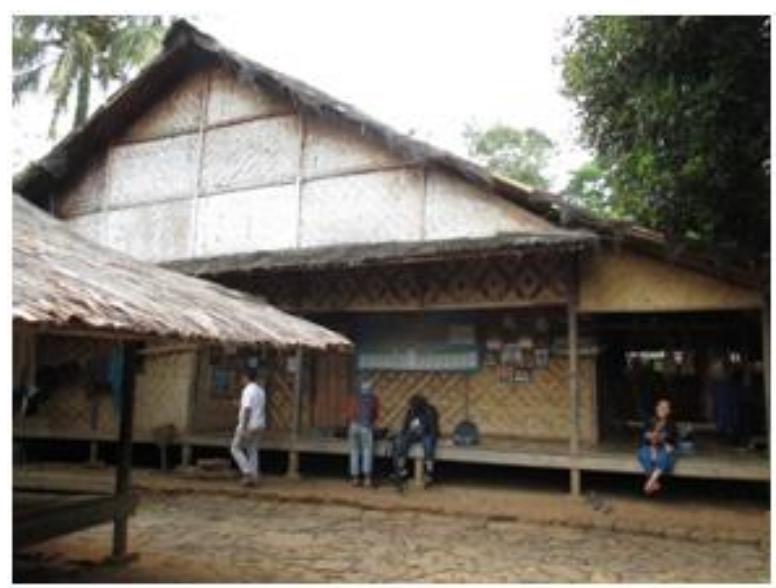

Gambar 3. Tampak depan rumah Ketua adat Kampung Tradisional Baduy

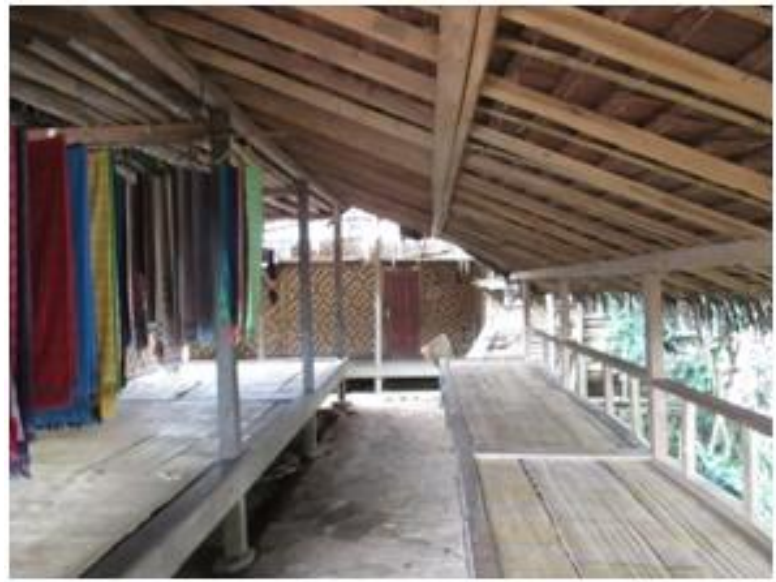

Gambar 4. Tampak kanan rumah Ketua adat Kampung Tradisional Baduy

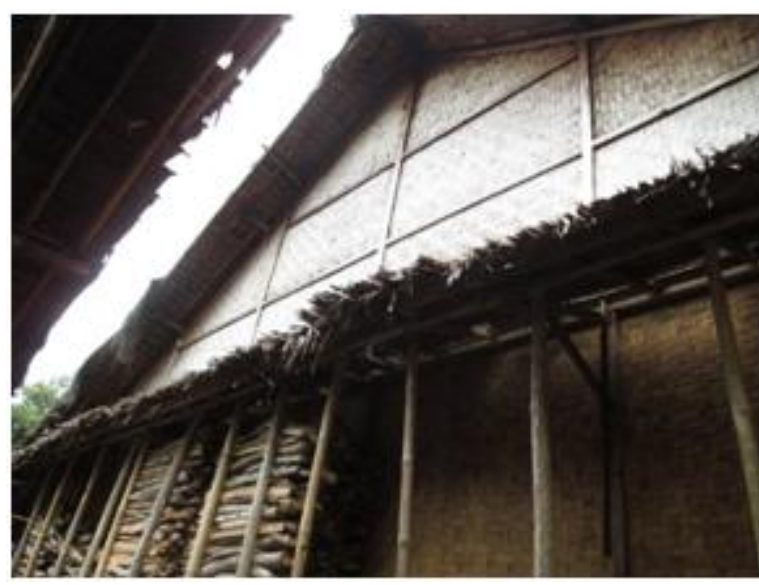

Gambar 5. Tampak Belakang rumah Ketua adat Kampung Tradisional Baduy

\section{Bangunan tipe 2: bangunan rumah} warga

Bangunan rumah ini adalah bangunan Baduy yang telah sedikitnya mengikuti perkembangan zaman yang ada, dimana bangunan menggunakan konstruksi dengan sistem sambungan paku sebagai penguatnya (Gambar 6,7,8,9 dan 10).

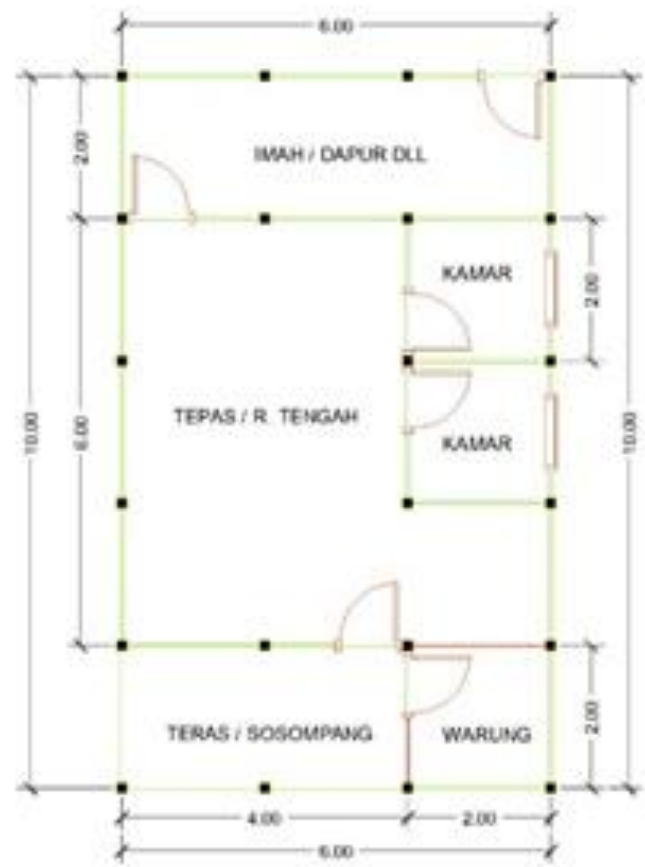

Gambar 6. Denah Rumah Baduy Luar 


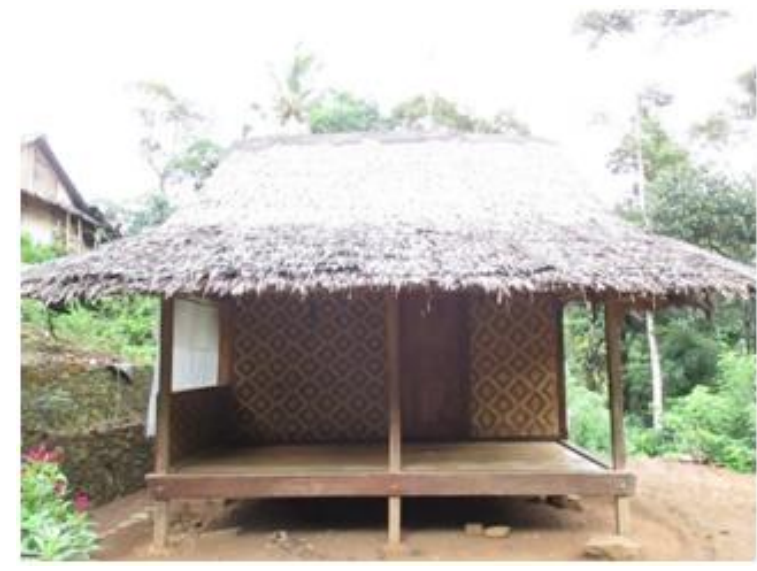

Gambar 7. Tampak depan rumah

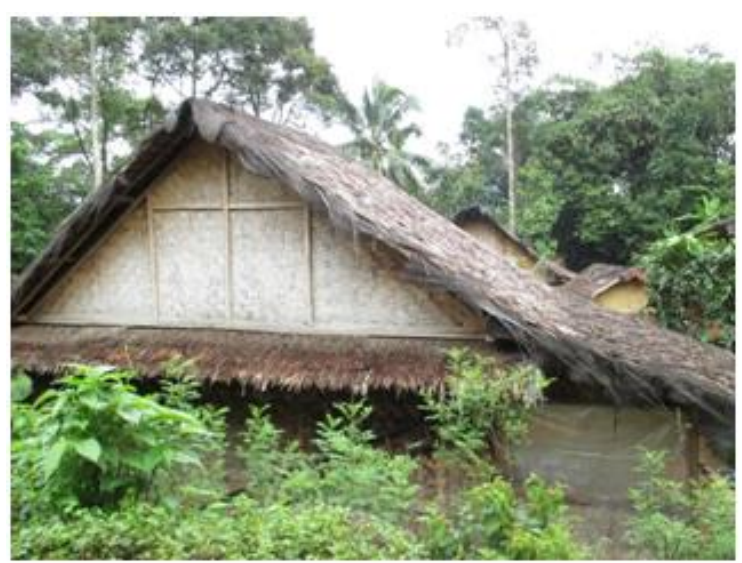

Gambar 8. Tampak kanan rumah

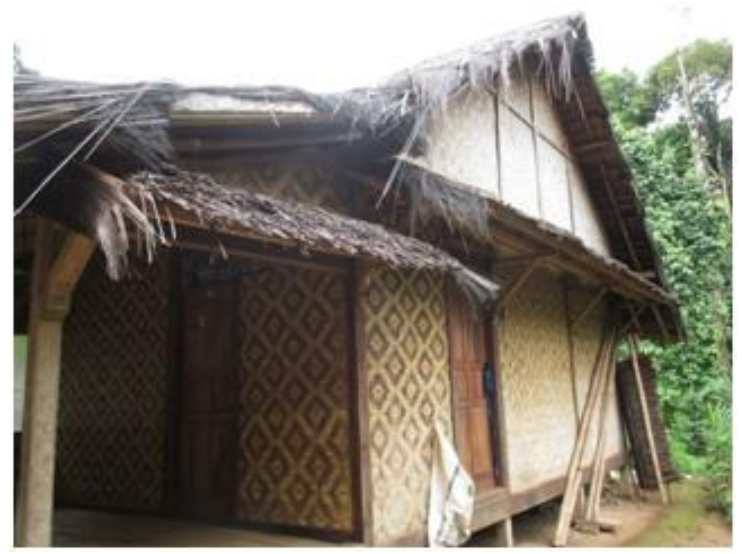

Gambar 9. Tampak kiri rumah

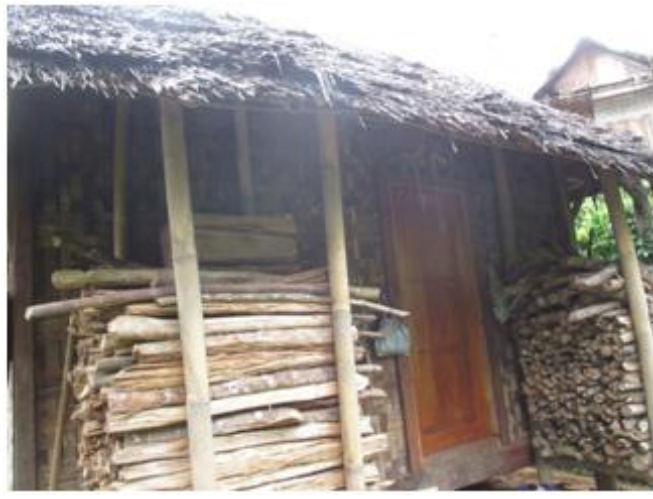

Gambar 10. Tampak belakang rumah Baduy Luar 1

4. Bangunan tipe 3: bangunan leuit

Leut digunakan sebagai tempan menyimpan hasil panel, khususnya padi (Gambar 11,12,13 dan 14).

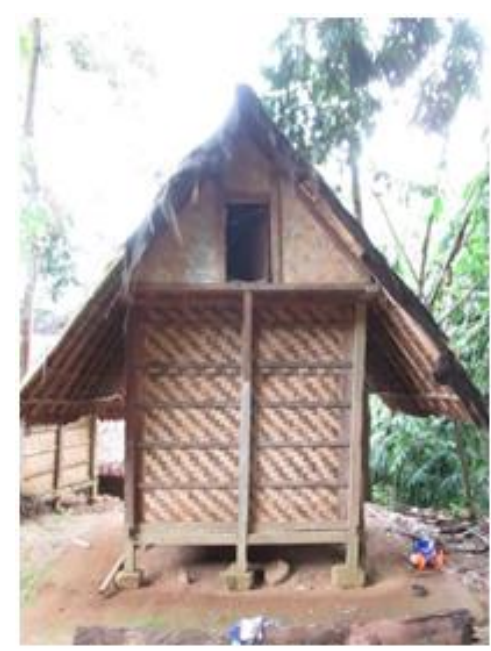

Gambar 11. Tampak depan leuit

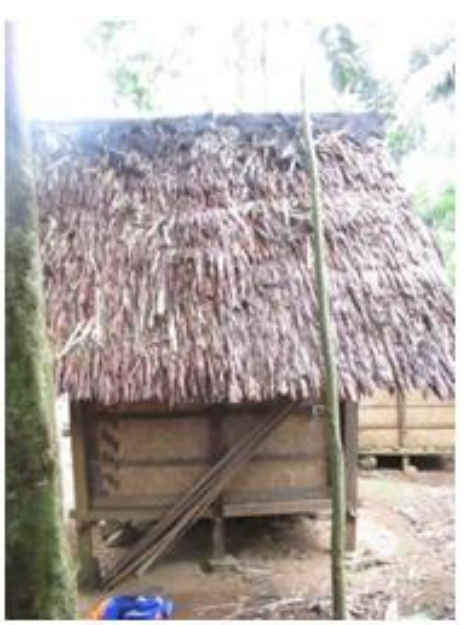

Gambar 12: Tampak kanan leuit 


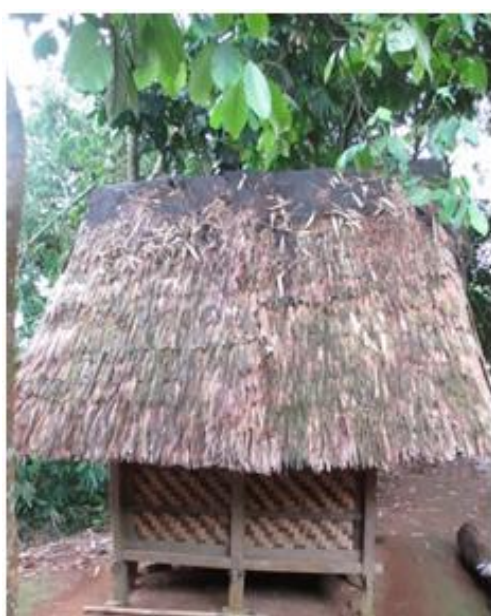

Gambar 13. Tampak kiri leuit

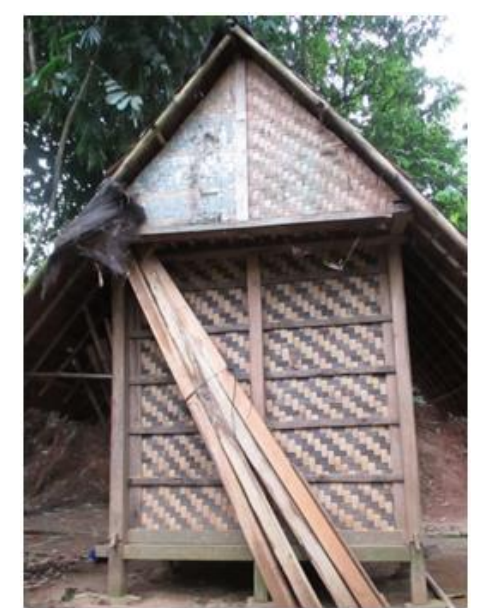

Gambar 14. Tampak belakang leuit

5. Bangunan tipe 4: bangunan jamban Jamban merupakan fasilitas umum di Kampung Kadu Ketug, yang digunakan secara bersama-sama (Gambar 15,16 dan 17).

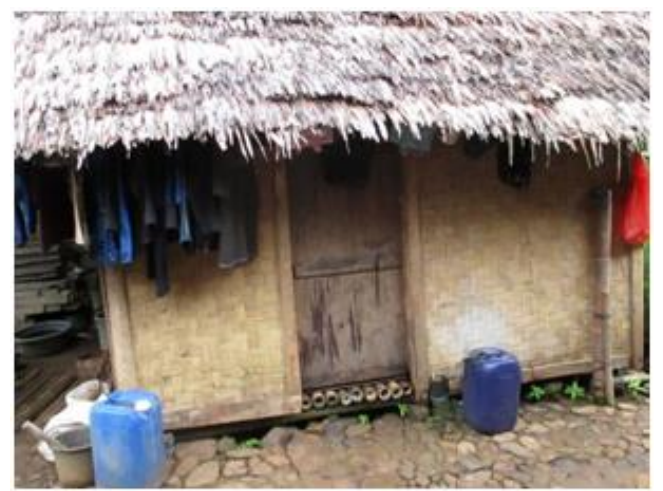

Gambar 15 : Tampak depan jamban

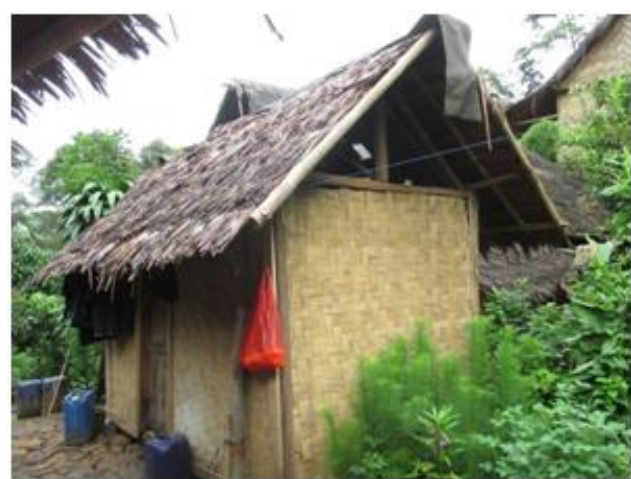

Gambar 16: Tampak kanan jamban

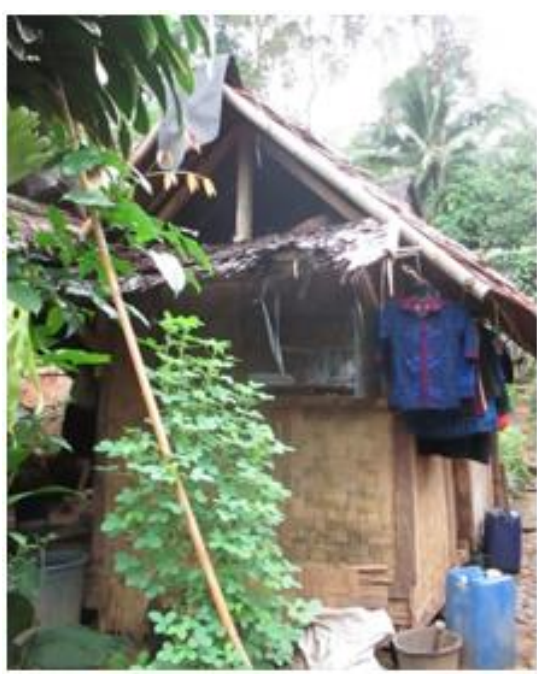

Gambar 17: Tampak kiri jamban

\section{Sistem Bangunan Rumah Tradisional}

6.1. Bangunan rumah ketua adat

6.1.1. Bagian bawah Bangunan

\section{Pondasi}

Pondasi yang dipergunakan pada rumah Ketua adat adalah batu kali yang kurang lebih berukuran 40 x $40 \mathrm{~cm}$ dengan ketebalan kurang lebih $20 \mathrm{~cm}$. batu tersebut berpijak pada tanah keras yang dimana Pondasi tersebut dibebani oleh tiang kayu berukuran $20 \times 20 \mathrm{~cm}$ tepat diatas setiap pondasi batu tersebut (Gambar 18). 


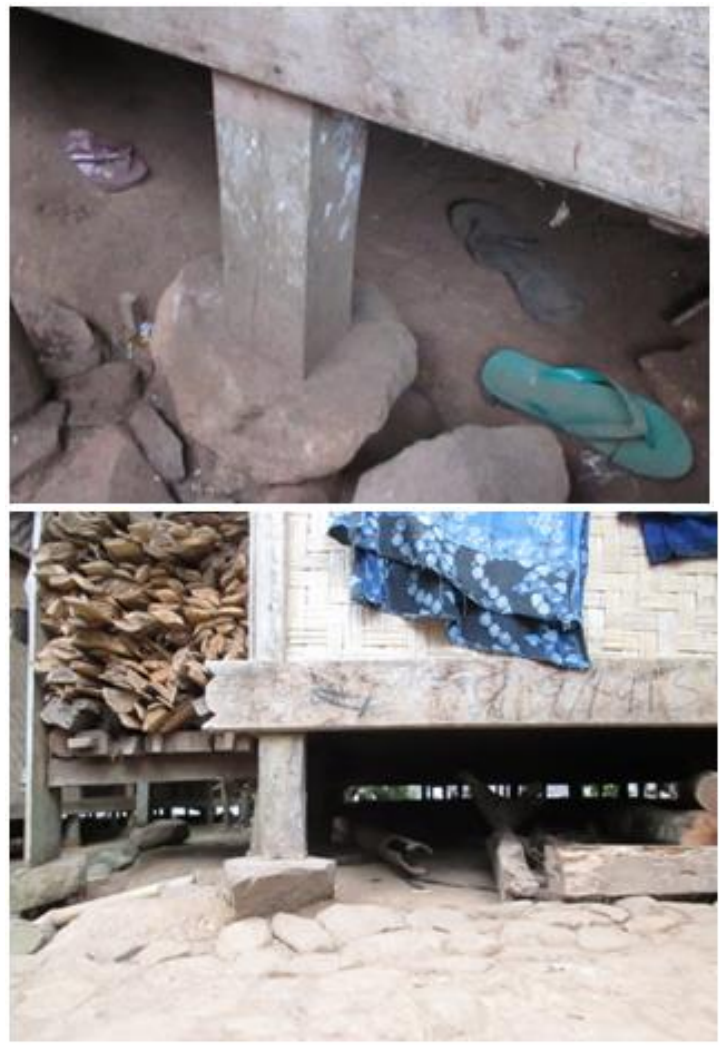

Gambar 18. Pondasi rumah ketua adat

\section{Lantai}

Lantai Pada Rumah ketua Adat kampung Tradisional Baduy ini menggunakan lantai dengan material Bambu, bentuknya dimana Bambu dipecah menjadi potongan-potongan kecil yang memanjang sehingga Bambu yang semula berbentuk lingkaran menjadi rata.berbeda dengan pondasi yang tidak memiliki sambungan dan lain sebagainya, bagian lantai ini menggunakan Paku sebagai media penguat antara penopang dibawahnya. Balok-balok yang menopang lantai ini adalah jajaran bilah-bilah bambu yang berbentuk silinder utuh yang dimana struktur dan fleksibelitasnya tinggi (Gambar 19 dan 20).

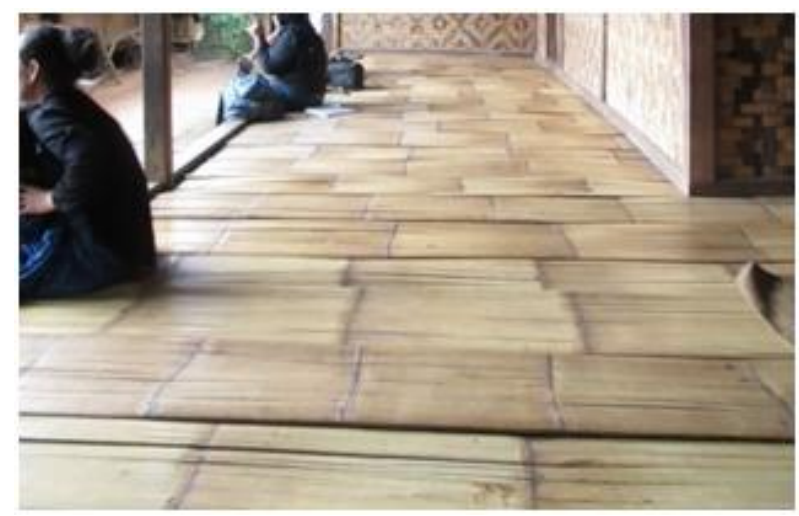

Gambar 19. Lantai bambu rumah ketua adat

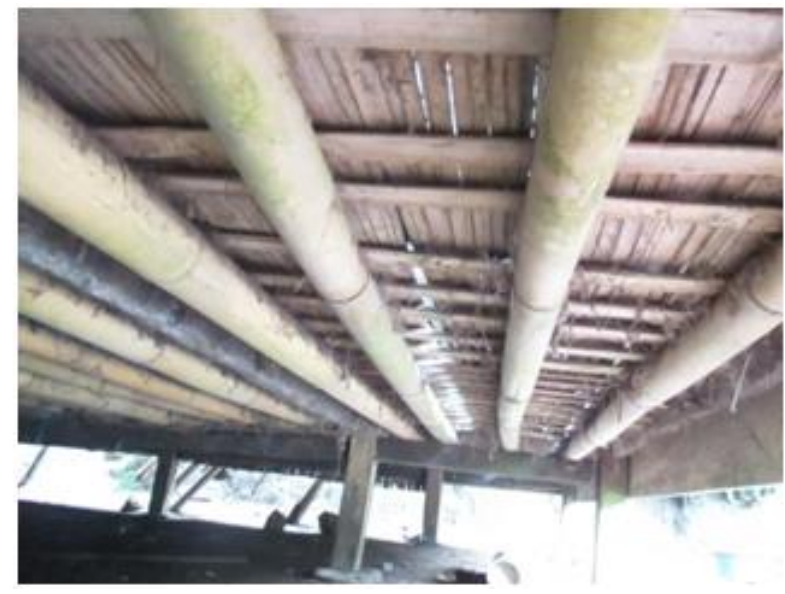

Gambar 20. Balok sebagai penguat bambu untuk lantai

\subsubsection{Bagian Tengah Bangunan}

\section{Dinding}

Dinding yang digunakan oleh bangunan adalah anyaman bambu, yang dimana anyaman ini mampu bertahan hingga usia 5 tahun. Dinding Anyaman Bambu ini merupakan Dinding yang memiliki "pori-pori" sehingga udara dalam bangunan bisa terus berganti dengan udara baru, sehingga orang-orang yang berada didalam bangunan lebih sehat (Gambar 21 dan 22).

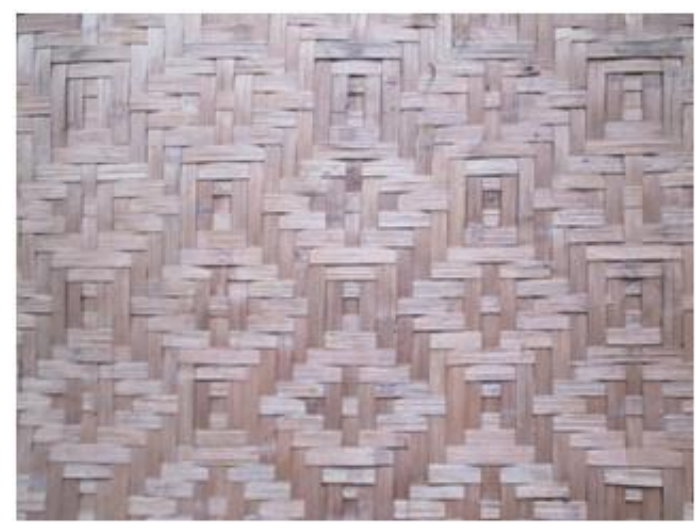

Gambar 21. Dinding anyaman rumah ketua adat 


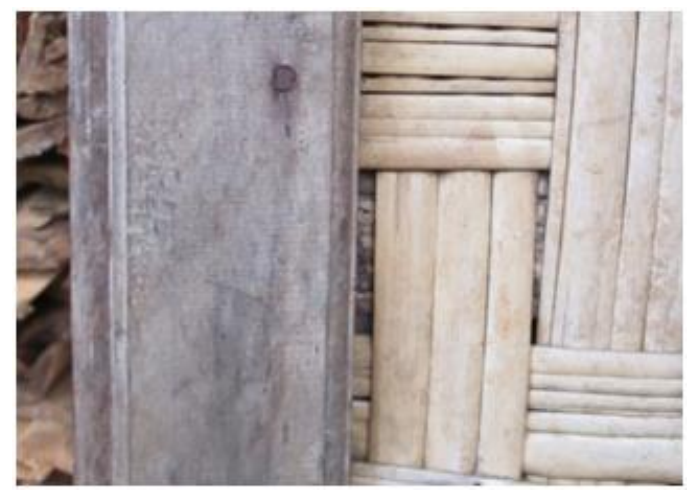

Gambar 22. Sambungan kolom kayu dengan dinding anyaman menggunakan paku sebagai media penguat pada rumah ketua adat

\section{Kolom}

Kolom pada Rumah Ketua Adat menggunakan kayu sebagai konstruksinya, dengan dimensi sekitar 15 hingga $20 \mathrm{~cm}$ kolom kayu tersebut mampu menopang berat dari lantai, dinding, hingga seluruh beban atap diatasnya. Jarak antara kolom kayu ini berkisar dari 2 sampai 3,5 meter. Dengan menggunakan kayu ini menjadikan pula bangunan memiliki light construction sehingga pada saat gempa Kayu kayu tersebut memiliki daya renggang yang baik (Gambar 23). Tapi memiliki kelemahan juga yaitu apabila rumah terbakar maka cepat pula rumah itu hilang karna habis terbakar.

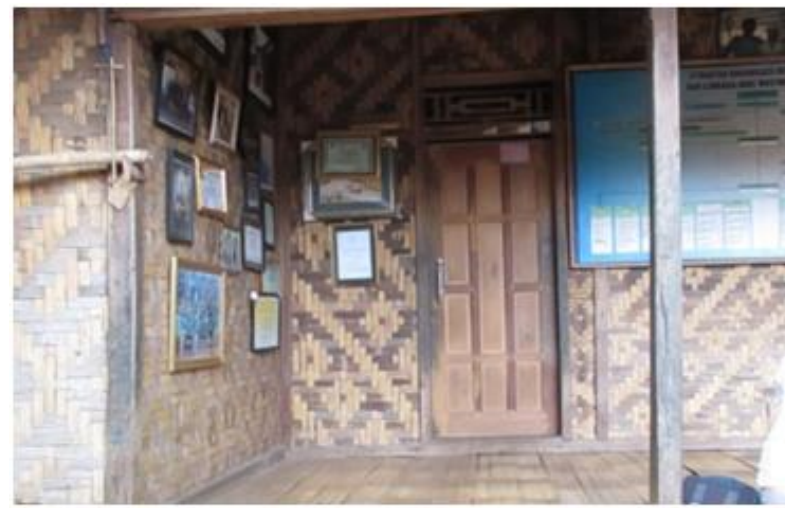

Gambar 23. Kolom kayu menghubungkan antara balok lantai dengan balok atap, paku sebagai media penguat pada rumah ketua adat

\section{Pintu dan Jendela}

Pada rumah Ketua Adat pintu yang dimiliki sudah menggunakan kayu modern, dimana bahkan pintu tersebut telah buat dan hanya tinggal dipasang kepada bangunanya saja selayaknya bangunan pada umumnya, kemudian untuk jendela tidak memiliki banyak, karena hakekatnya dinding anyaman itupun bisa difungsikan sebagai media penglihatan menuju keluar (Gambar 24).

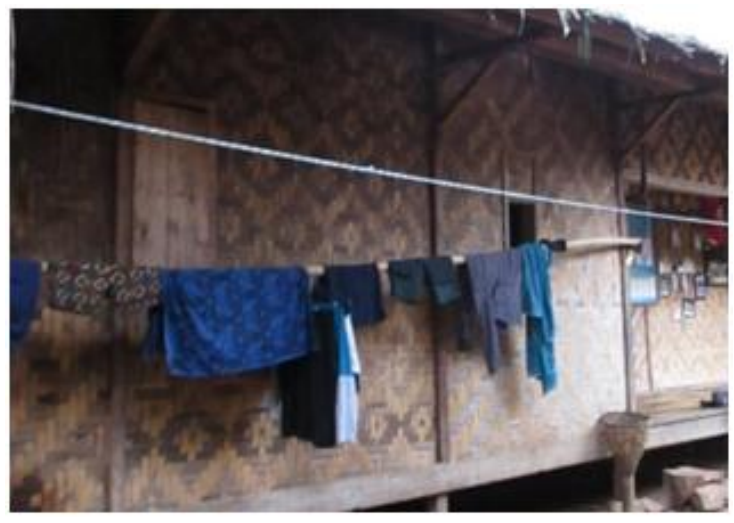

Gambar 24. Jendela rumah kepala adat

\section{Bagian Atas Bangunan}

\section{Langit-langit}

Langit-langit bangunan rumah Ketua adat ini menggunakan bahan yang sama dengan dinding yaitu anyaman bambu. Kekuatan anyaman bamboo ini bisa sampai 5 tahun, dan mampu memberikan sirkulasi udara yang baik bagi ruang didalam bangunan (Gambar 25).

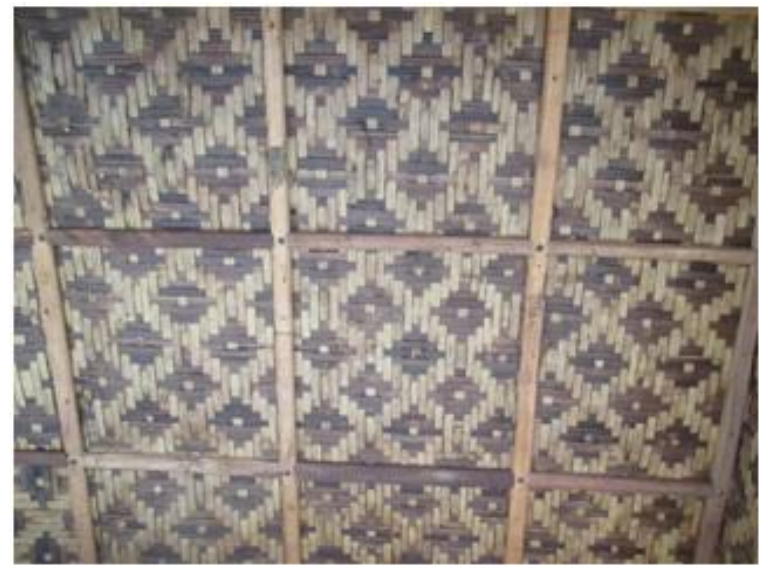

Gambar 25. Pola langit-langit pada rumah ketua adat, menggunakan penahan bambu dengan penahan berupa paku yang di sambungkan ke rangka atap

\section{Rangka Atap}

Rangka atap pada bangunan ini menggunakan kayu sebagai konstruksinya. Dengan bentukan sederhana pelana dengan patahan kedalam. Kekuatan rangka kayu ini bisa tahan hingga usia 30 tahun, tetapi tergantung dari jenis pohon yang dipakai dan kelembaban dari batang kayu tersebut (Gambar 26 dan 27). 


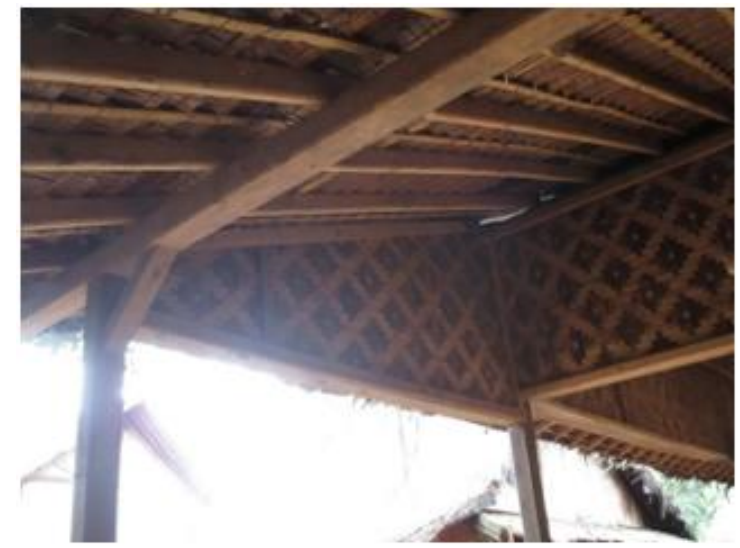

Gambar 26. Rangka bubungan atap menggunakan bambu utuh berdiameter $6 \mathrm{~cm}$

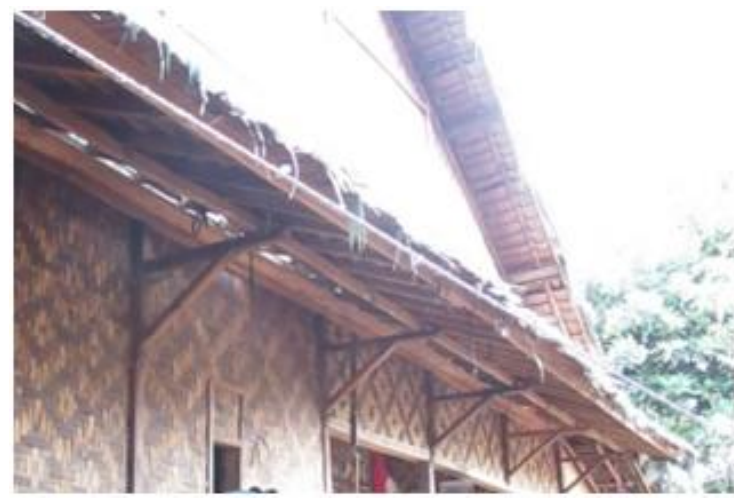

Gambar 27. Rangka kanopi atap menggunakan bambu utuh berdiameter $4 \mathrm{~cm}$

\section{Penutup Atap}

Penutup Atap dari Rumah Ketua adat ini menggunakan injuk sebagai pelindung dari panas dan hujan (Gambar 28).

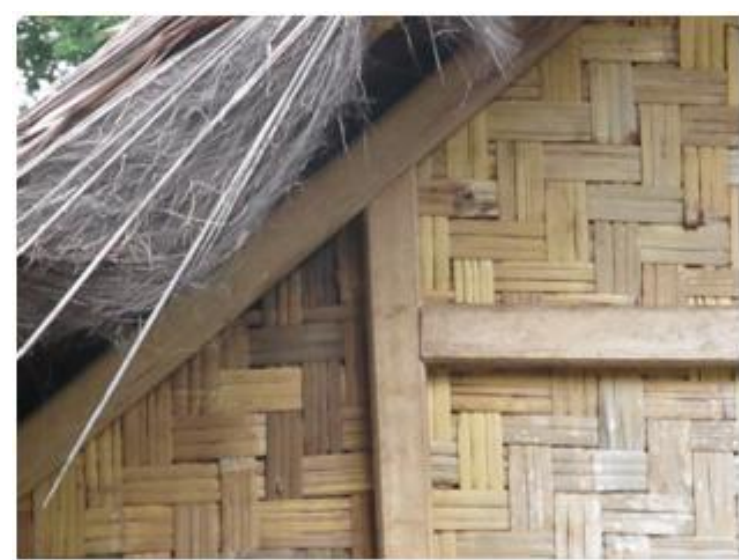

Gambar 28. Penutup atap rumah ketua adat menggunakan ijuk sebagai pelindung rumahnya

\section{Pondasi}

Pondasi yang dipergunakan pada rumah Baduy Luar1 adalah batu kali yang kurang lebih berukuran 30 x $30 \mathrm{~cm}$ dengan ketebalan kurang lebih $20 \mathrm{~cm}$. batu tersebut berpijak pada tanah keras yang dimana Pondasi tersebut dibebani oleh tiang kayu berukuran $20 \times 20 \mathrm{~cm}$ tepat diatas setiap pondasi batu tersebut. Yang menarik adalah untuk rumah yang berada di daerah Baduy luar, area tanah yang menjadi lahan bangun itu boleh diubah konturnya, sehingga rumah-rumah yang berada di Baduy Luar rata-rata memiliki rumah yang rata dengan tanah (Gambar 29).

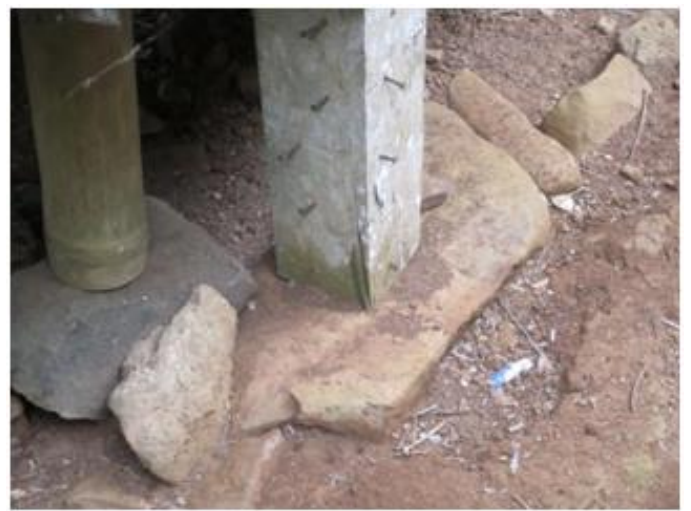

Gambar 29. Pondasi batu kali yang menapak pada tanah keras

\section{Lantai dan Balok}

Lantai Pada Rumah Baduy luar 1 kampung Tradisional Baduy ini menggunakan lantai dengan material Bambu, bentuknya dimana Bambu dipecah menjadi potongan-potongan kecil yang memanjang sehingga Bambu yang semula berbentuk lingkaran menjadi rata.berbeda dengan pondasi yang tidak memiliki sambungan dan lain sebagainya, bagian lantai ini menggunakan Paku sebagai media penguat antara penopang dibawahnya (Gambar 30). Balok-balok yang menopang lantai ini adalah jajaran bilah-bilah kayu yang berukuran $6 \times 8 \mathrm{~cm}$ yang dimana struktur dan fleksibelitasnya tinggi (Gambar 31).

\subsection{Bangunan Rumah Warga Kadu Ketug 6.2.1. Bagian bawah bangunan}




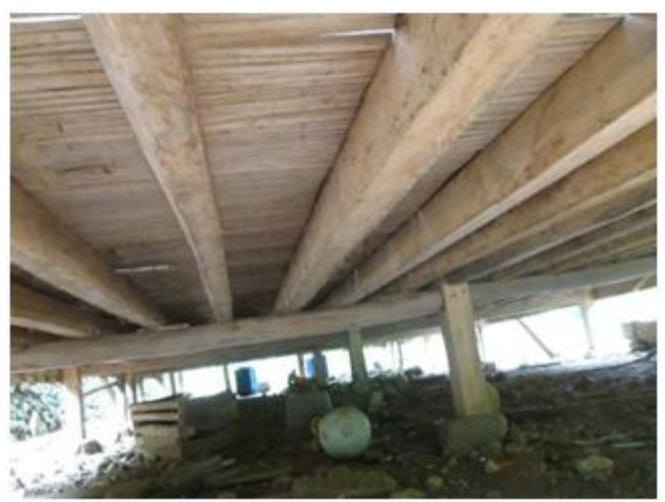

Gambar 30. Balok-balok kayu penahan beban tekan dari lantai yang kemudian disalurkan ke pondasi batu kali yang menapak pada tanah keras

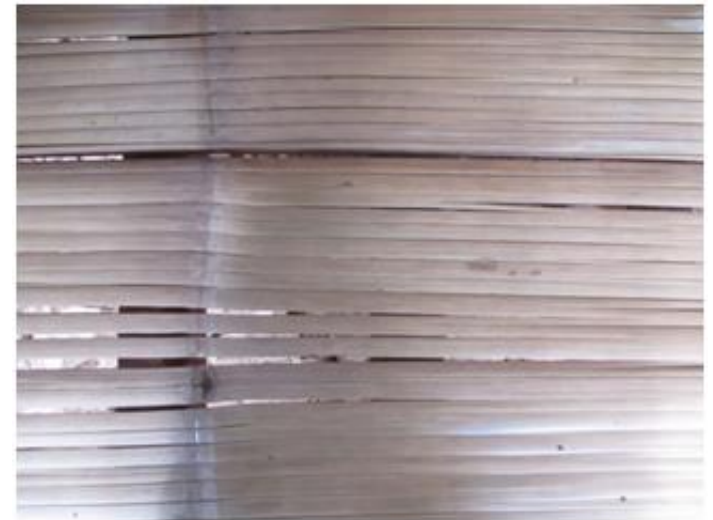

Gambar 31. Lantai bamboo yang buat lembarn dengan dipecah agar dapat rata lantai

\subsubsection{Bagian Tengah Bangunan}

\section{Dinding}

Dinding yang digunakan oleh bangunan adalah anyaman bambu, yang dimana anyaman ini mampu bertahan hingga usia 5 tahun (Gambar 32). Dinding Anyaman Bambu ini merupakan Dinding yang memiliki "pori-pori" sehingga udara dalam bangunan bisa terus berganti dengan udara baru, sehingga orang-orang yang berada didalam bangunan lebih sehat.

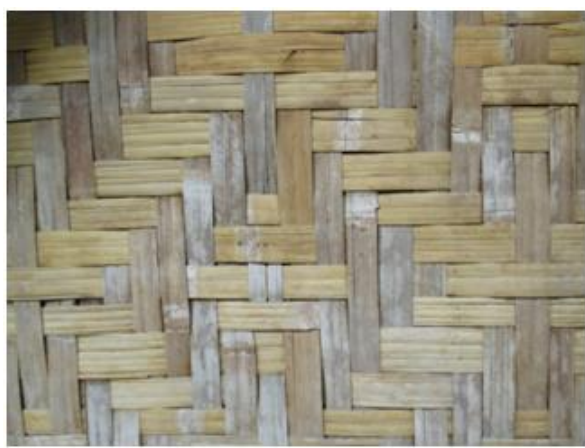

Gambar 32. Dinding pada rumah

\section{Kolom}

Kolom pada Rumah Baduy luar 1 menggunakan kayu sebagai konstruksinya, dengan dimensi sekitar 15 hingga $20 \mathrm{~cm}$ kolom kayu tersebut mampu menopang berat dari lantai, dinding, hingga seluruh beban atap diatasnya. Jarak antara kolom kayu ini berkisar dari 2 ampai 3,5 meter. Dengan menggunakan kayu ini menjadikan pula bangunan memiliki light construction sehingga pada saat gempa Kayu kayu tersebut memiliki daya renggang yang baik (Gambar 33 dan 34). Tapi memiliki kelemahan juga yaitu apabila rumah terbakar maka cepat pula rumah itu hilang karna habis terbakar.

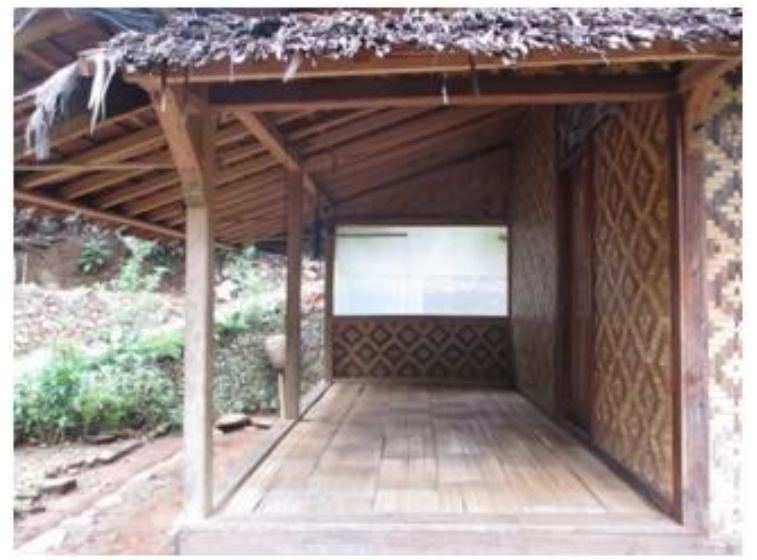

Gambar 33. Kolom pada rumah Baduy Luar 1

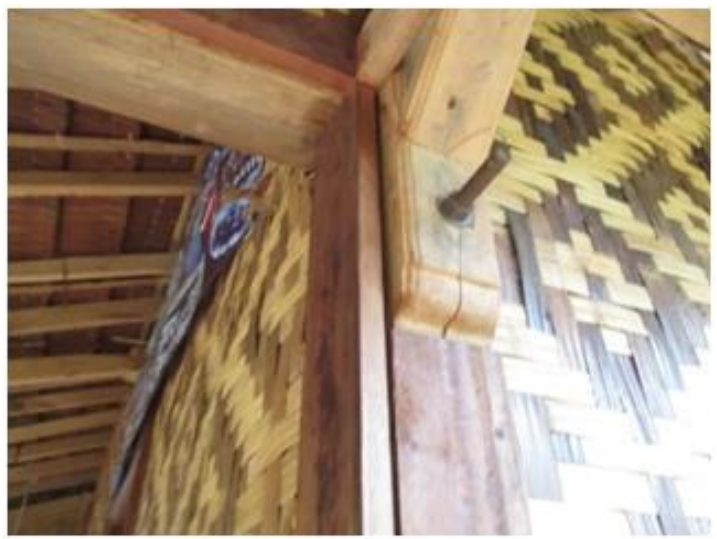

Gambar 34. Detail kolom yang menggunakan besi anker sebagai penguat bangunan

\section{Pintu dan Jendela}

Pada rumah Baduy Luar 1 pintu yang dimiliki sudah menggunakan kayu modern, dimana bahkan pintu tersebut telah buat dan hanya tinggal dipasang kepada bangunanya saja selayaknya bangunan pada umumnya, kemudian untuk jendela tidak memiliki banyak, karena

Edisi cetak 
hakekatnya dinding anyaman itupun bisa difungsikan sebagai media penglihatan menuju keluar (Gambar 35).

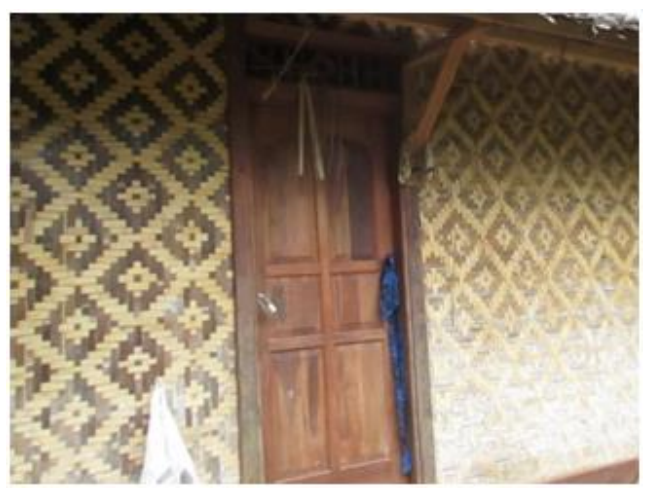

Gambar 35. Penggunaaan kusen kayu yang memiliki motif pada rumah Baduy Luar

\subsubsection{Bagian Atas Bangunan}

\section{Langit-langit}

Langit-langit bangunan rumah Baduy luar 1 ini tidak menggunakan penutup layaknya dirumah ketua adat, tetapipenutupnya langsung dari penutup atanya itu sendiri (Gambar 36).

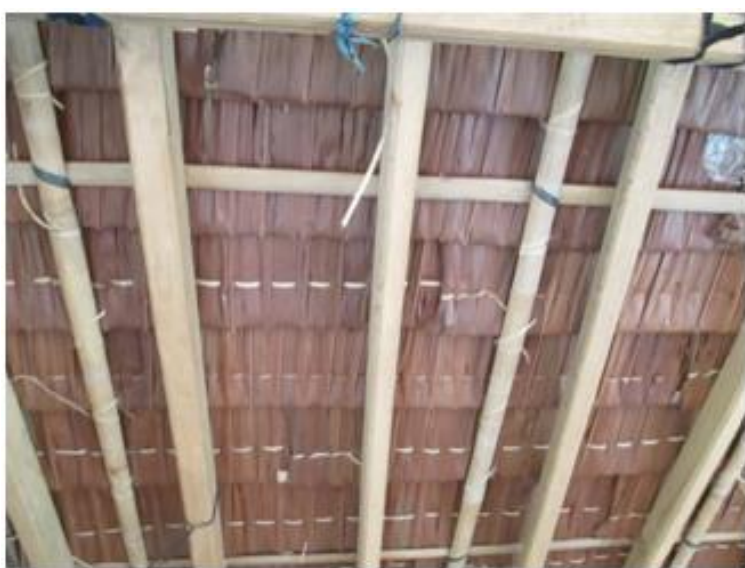

Gambar 36. Penggunaaan atap daun kelapa kering sebagai penutup atap sekaligus sebagai langit-langit bangunanpada rumah Baduy Luar 1

\section{Rangka Atap}

Rangka Atap pada Bangunan ini menggunakan Kayu sebagai Konstruksinya (Gambar 37). Dengan bentukan sederhana pelana dengan patahan kedalam. Kekuatan rangka kayu ini bisa tahan hingga usia 30 tahun, tetapi tergantung dari jenis pohon yang dipakai dan kelembaban dari batang kayu tersebut.

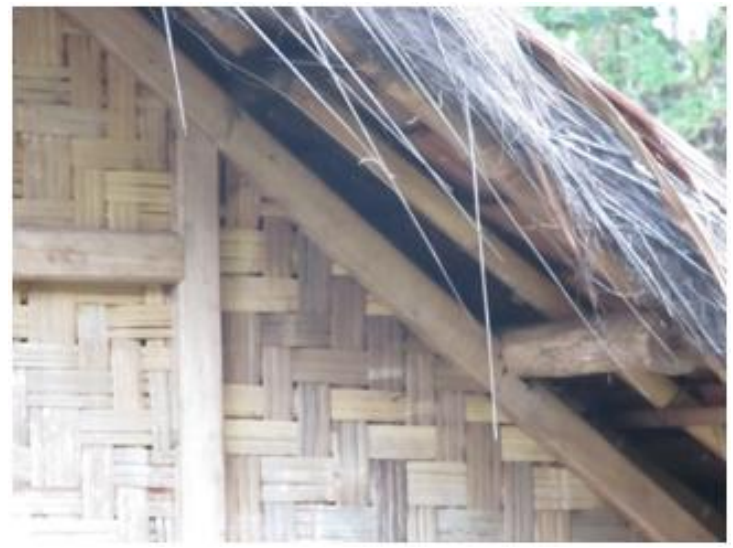

Gambar 37. Penggunaaan Bambu untuk gording pada struktur kayu pada rumah Baduy Luar 1

\section{Penutup Atap}

Penutup Atap dari Rumah Ketua adat ini menggunakan penutup daun kelapa kering sebagai pelindung dari panas dan hujan. Sementara ujung dari setiap atapnya menggunakan juga injuk yang fungsinya sebagai list atap (Gambar 38).

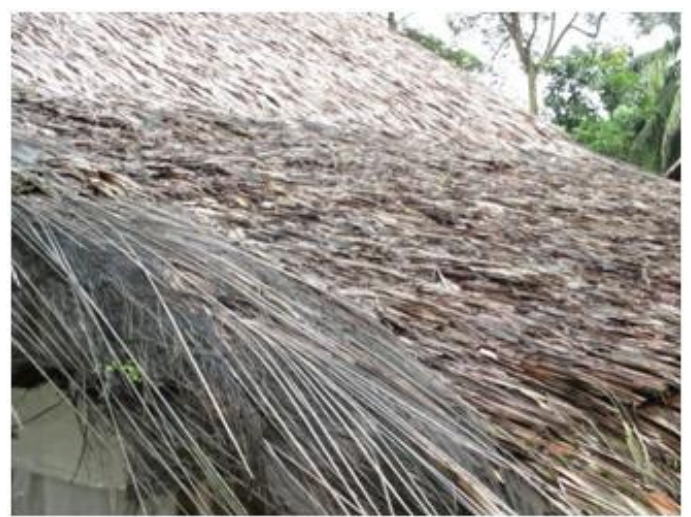

Gambar 38. Penggunaaan penutup atap daun kelapa kering pada rumah Baduy Luar 1

\subsection{Bangunan leuit \\ 6.3.1. Bagian bawah Bangunan}

\section{Pondasi}

Pondasi yang dipergunakan pada rumah Baduy Luar 1 adalah batu kali yang kurang lebih berukuran $30 \times 30 \mathrm{~cm}$ dengan ketebalan kurang lebih $20 \mathrm{~cm}$ (Gambar 39). Batu tersebut berpijak pada tanah keras yang dimana Pondasi tersebut dibebani oleh tiang kayu berukuran $20 \times 20 \mathrm{~cm}$ tepat diatas setiap pondasi batu tersebut. 


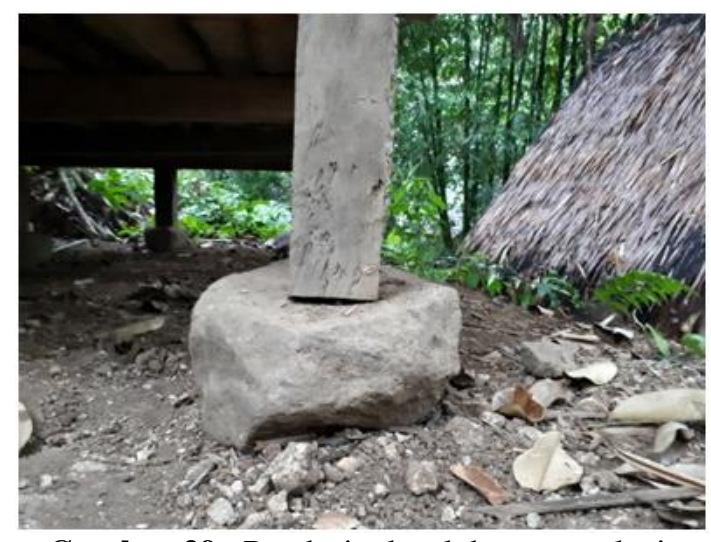

Gambar 39. Pondasi telapak bangunan leuit

\section{Lantai dan Balok}

Lantai pada leuit ini menggunakan lantai dengan material Bambu, bentuknya dimana Bambu dipecah menjadi potongan-potongan kecil yang memanjang sehingga Bambu yang semula berbentuk lingkaran menjadi rata.berbeda dengan pondasi yang tidak memiliki sambungan dan lain sebagainya, bagian lantai ini menggunakan Paku sebagai media penguat antara penopang dibawahnya (Gambar 40). Balok-balok yang menopang lantai ini adalah jajaran bilah-bilah bambu yang berbentuk silinder utuh yang dimana struktur dan fleksibelitasnya tinggi.

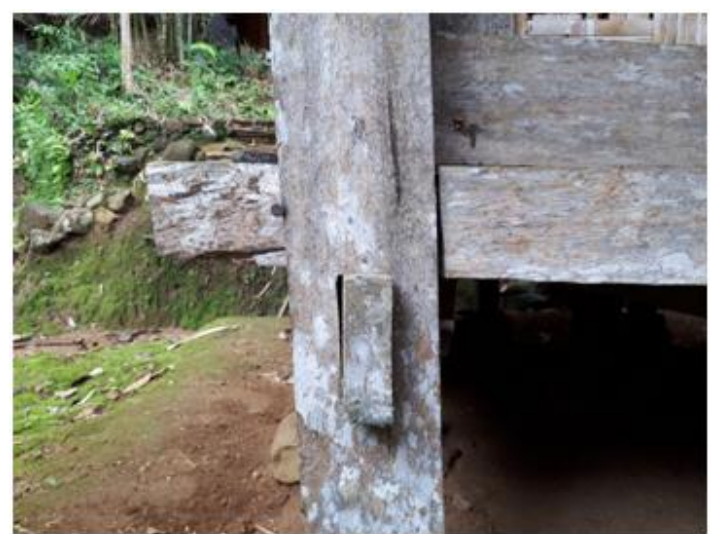

Gambar 40. Balok lantai leuit

\subsubsection{Bagian Tengah Bangunan}

\section{Dinding}

Dinding yang digunakan oleh bangunan adalah anyaman bambu, yang dimana anyaman ini mampu bertahan hingga usia 5 tahun. Dinding Anyaman Bambu ini merupakan Dinding yang memiliki "pori-pori" sehingga udara dalam bangunan bisa terus berganti dengan udara baru (Gambar 41).

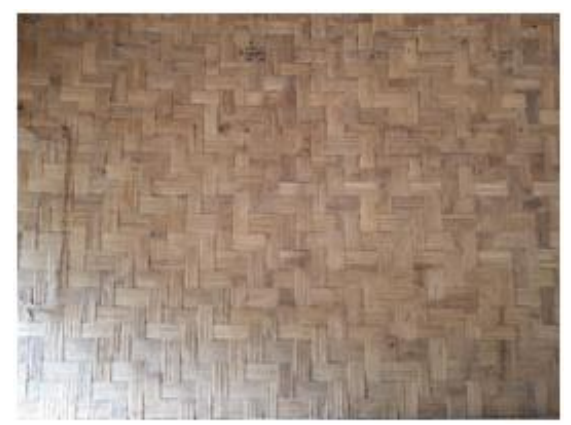

Gambar 41. Dinding Leuit

Kolom

Kolom menggunakan kayu sebagai konstruksinya, dengan dimensi sekitar 15 hingga $20 \mathrm{~cm}$ kolom kayu tersebut mampu menopang berat dari lantai, dinding, hingga seluruh beban atap diatasnya (Gambar 41). Jarak antara kolom kayu ini berkisar dari 2 sampai 3,5 meter. Dengan menggunakan kayu ini menjadikan pula bangunan memiliki light construction sehingga pada saat gempa. Kayukayu tersebut memiliki daya renggang yang baik. Tapi memiliki kelemahan juga yaitu apabila rumah terbakar maka cepat pula rumah itu hilang karna habis terbakar. Kemudian dari kolom Leuit Baduy Luar 2 ini memiliki variasi yang berbeda dengan jumlah kolom sebanyak 9 tihang.

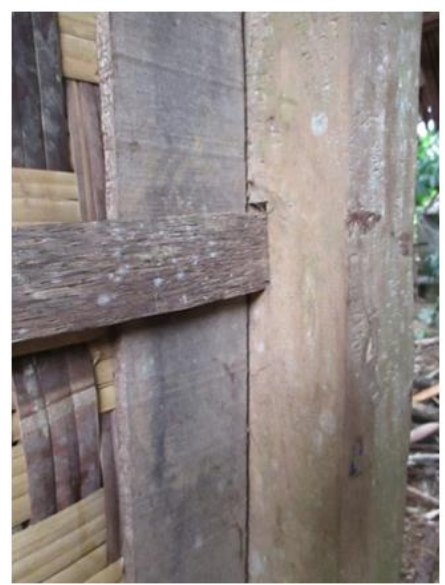

Gambar 41. Kolom Leuit

\section{Pintu}

Pada pintu yang ditempatkan pada area atas berfungsi sebagai mencegah orang untuk mencuri, dengan ukuran $60 \times 100 \mathrm{~cm}$ dan berada di ketinggian 2,3 meter. Dengan penutup pintunya menggunakan kayu (Gamabr 42). 


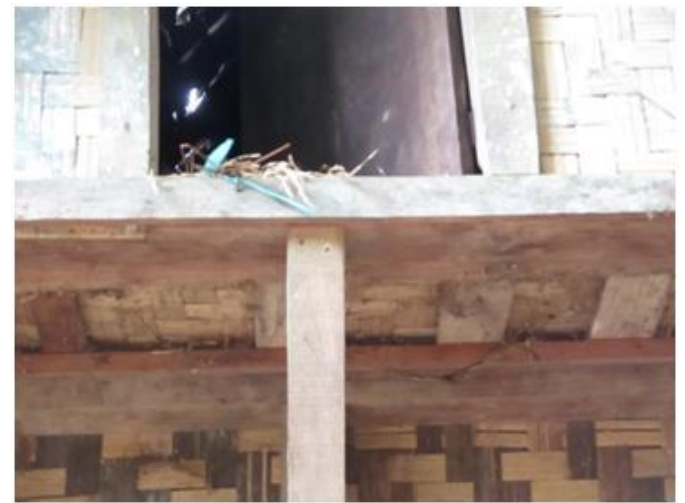

Gambar 42. Pintu Leuit

\subsubsection{Bagian Atas Bangunan}

\section{Langit-langit}

Tidak menggunakan langit-langit media penutup atap berfungsi sebagai langit-langit.

\section{Rangka Atap}

Rangka Atap pada Bangunan ini menggunakan Kayu sebagai Konstruksinya. Dengan bentukan sederhana pelana dengan patahan kedalam (Gambar 43). Kekuatan rangka kayu ini bisa tahan hingga usia 30 tahun, tetapi tergantung dari jenis pohon yang dipakai dan kelembaban dari batang kayu tersebut.

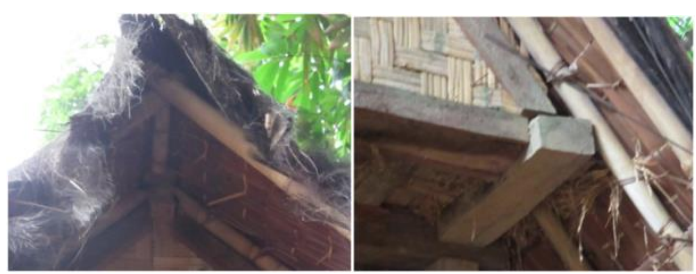

Gambar 43. Rangka atap Leuit

\section{Penutup Atap}

Penutup atap menggunakan ijuk yang dicampur dengan daun kelapa yang dikeringkan sebagai pelindung dari panas dan hujan.

\subsection{Bangunan jamban (fasilitas bersama) 6.4.1. Bagian Bawah}

\section{Pondasi}

Pondasi yang dipergunakan pada Jamban Baduy Luar 1 adalah batu kali yang kurang lebih berukuran $30 \times 30 \mathrm{~cm}$ dengan ketebalan kurang lebih $20 \mathrm{~cm}$ (Gambar 44). batu tersebut berpijak pada tanah keras yang dimana Pondasi tersebut dibebani oleh tiang kayu berukuran $20 \times 20 \mathrm{~cm}$ tetapi menapaknya pendek kisaran panjangnya sekitar $5 \mathrm{~cm}$. sedangkan tinggi tihang atau kolom yang berpijak pada batu di bangunan rumah sepanjang $35 \mathrm{~cm}$.

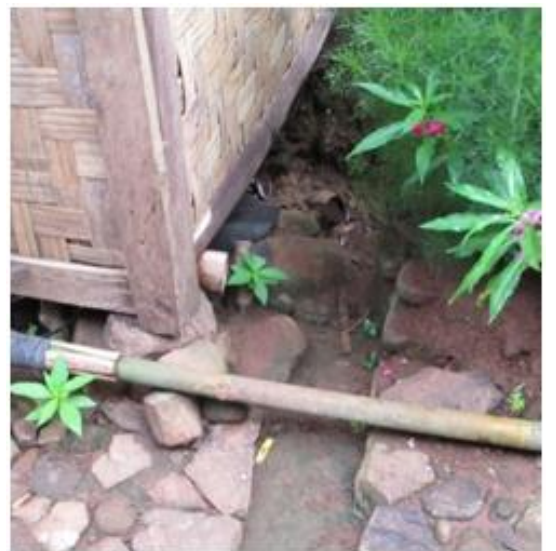

Gambar 44. Pondasi jamban Baduy Luar 1

\section{Lantai dan Balok}

Lantai Pada Jamban Baduy ini menggunakan lantai dengan material Bambu, bentuknya dimana Bambu tersebut dibiarkan berjajar sehingga ada sela-sela yang dapat dilalui air, yang di bawah lantai tersebut terdapat saluran air (Gambar 45).

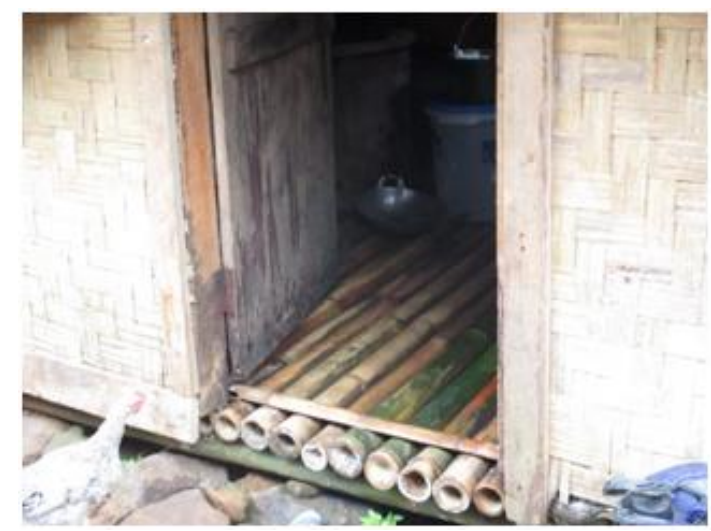

Gambar 45. Lantai Jamban Baduy Luar 1

\subsubsection{Bagian Tengah Bangunan}

\section{Dinding}

Dinding yang digunakan oleh bangunan adalah anyaman bambu, yang dimana anyaman ini mampu bertahan hingga usia 5 tahun (Gambar 46). Dinding Anyaman Bambu ini merupakan Dinding yang memiliki "pori-pori" sehingga udara dalam bangunan bisa terus berganti dengan udara baru. 


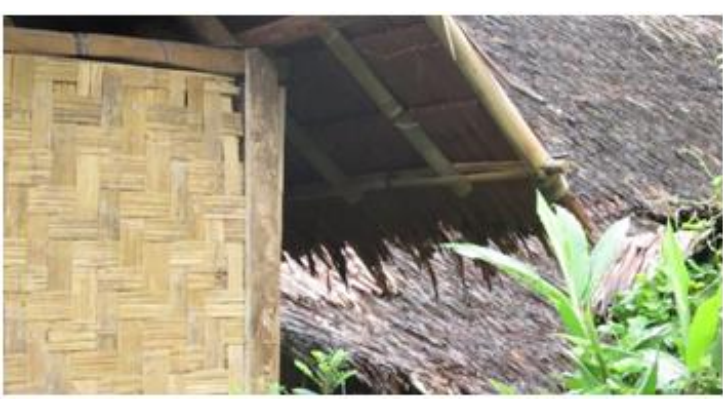

Gambar 46. Dinding jamban Baduy Luar 1

\section{Kolom}

Kolom pada Jamban ini menggunakan kayu sebagai konstruksinya, dengan dimensi sekitar $10 \mathrm{~cm}$ kolom kayu tersebut mampu menopang berat dari lantai, dinding, hingga seluruh beban atap diatasnya.

\section{Pintu dan Jendela}

Pada Jamban tersebut hanya memiliki satu pintu sebagai akses dan diatasnya hanya terdapat lubang ventilasi.

\subsubsection{Bagian Atas Bangunan}

\section{Langit-langit}

Tdak menggunakan langit-langit, langsung beratapkan penutup atap pelepah kelapa kering sebagai pelindung.

\section{Rangka Atap}

Rangka Atap pada Bangunan ini menggunakan Kayu sebagai Konstruksinya. Dengan bentukan sederhana pelana. Kekuatan rangka kayu ini bisa tahan hingga usia 30 tahun, tetapi tergantung dari jenis pohon yang dipakai dan kelembaban dari batang kayu tersebut.

\section{Penutup Atap}

Penutup Atap dari Rumah Ketua adat ini menggunakan penutup daun kelapa kering sebagai pelindung dari panas dan hujan.

\section{KESIMPULAN}

Tulisan ini memberikan gambaran pemetaan tipe-tipe bangunan rumah di Kampung Adat Baduy Luar Kadu Ketug, serta memberikan gambaran sistem dari setiap bangunan tersebut. Adapun kesimpulan yang didapatkan dari riset ini adalah:
1. Rumah di Kampung Adat Baduy Luar Kadu Ketug mirip dengan Kampung Adat Baduy Dalam, dengan perbedaan pada beberapa detail bagian dari bangunan tersebut. Pada bangunan rumah di Kampung Kadu Ketug Luar ini, beberapa bagian sudah dikembangkan dengan sistem modern, seperti penggunaan paku dakam sambungannya.

2. Tipe rumah masyarakat, tipikal sepereti rumah Sunda secara umum, tetapi pada Kampung Kadu Ketug ini sudah dikembangkan lebih modern akibat pengaruh teknologi, budaya luar dan kebutuhan ruang untuk keluarga.

3. Sistem bagian bawah bangunan untuk semua tipe bangunan terdiri atas 3 bagian, yaitu bagian bawah sebagai kaki, bagian tengah sebagai badan, dan bagian atas sebagai kepala. Sistem ini sampai sekarang tetap dipertahankan oleh masyarakat Kamoung Kadu Ketug.

4. Tukang yang membuat bangunan ini, dikerjakan oleh masyarakat Kadu Ketug, dimana pengetahuan pertukangan diteruskan secara turun temurun, walaupun sekarang sudah mulai menggunakan peralatan yang lebih modern dan dioengaruhi oleh sistem pertukangan yang lebih instan

\section{Daftar Pustaka}

Rapoport, Amos (2005) Culture, Architecture and Design. Chicago: Locke Science Publishing Company

Permana, R.C.E (2006) Tata Ruang Masyarakat Baduy. Jakarta: Wedatama Widya Sastra.

Hasman, D., \& F. Reiss (2012) Urang Kenekes, Baduy People. Jakarta: Indonesian Heritage Society. 